\title{
ROZPACZ I PRAGNIENIE CUDU - MILOSZ WOBEC ZDZIECHOWSKIEGO
}

\author{
LIDIA BANOWSKA ${ }^{1}$ \\ (Poznań) \\ Słowa kluczowe: Miłosz, Zdziechowski, zło, Bóg, cud \\ Keywords: Miłosz, Zdziechowski, evil, God, miracle
}

\begin{abstract}
Abstrakt: Lidia Banowska, ROZPACZ I PRAGNIENIE CUDU. „PORÓWNANIA” 10, 2012, Vol. X, s. 39-56, ISSN 1733-165X. Artykuł omawia relację między Miłoszem a Marianem Zdziechowskim (historykiem literatury, idei, myślicielem chrześcijańskim) na podstawie eseju Religijność Zdziechowskiego (1943) oraz wiersza Zdziechowski (tom To, 2000). Kluczowym problemem obu tekstów jest asymilacja filozofii pesymizmu w obręb chrześcijaństwa. Podejmując odwieczne pytanie teodycei, jak możliwe jest zło w świecie stworzonym przez dobrego Boga, Miłosz przedstawia odpowiedź Zdziechowskiego (podążającego za Secrétanem i Sołowjowem): świat jest skażony złem, jest bezładem i bezrozumem i jako taki nie mógł wyjść z ręki Boga. Rzeczywistości zła negującej istnienie Stwórcy i prowadzącej do rozpaczy przeciwstawiony jednak zostaje głos doświadczenia wewnętrznego rozpoznający istnienie Boga jako miłości. Ta sprzeczność logiczna, wymagająca przekroczenia przez rozum jego własnych ograniczeń, prowadzi myśliciela do odkrycia Boga jako niemożliwego, a istniejącego, jako cudu, który należy afirmować. Kreśląc portret profesora, Miłosz rozpoznaje $\mathrm{w}$ nim $\mathrm{w}$ jakiejś mierze własne rysy: wynikający z wrażliwości na cierpienie realizm doświadczenia, heroizm wiary i myślenia religijnego oraz "głód Boga", duchową tęsknotę za innym wymiarem, poruszającą nie tylko intelekt, ale i wyobraźnię.
\end{abstract}

Abstract: Lidia Banowska, DESPAIR AND LONGING FOR A MIRACLE - MIŁOSZ IN OPPOSITION TO ZDZIECHOWSKI "PORÓWNANIA" 10, 2012, Vol. X, p. 39-56. ISSN 1733-165X. The author discusses the relationship between Czesław Miłosz and Marian Zdziechowski (a historian of literature and of ideas, and a Christian thinker), on the basis of the essay Religijność Zdziechowskiego (Zdziechowski's Religiosity, my own translation) from 1943 and of the poem Zdziechowski from the volume To (It, my own translation) from 2000. The key problem in both texts is assimilation of the philosophy of pessimism into Christianity. Having posed the eternal question of theodicy: how is it possible for evil to exist in a world created by a good God, Miłosz presents Zdziechowski's answer, reminiscent of Charles Secrétan and Vladimir Solovyov,

${ }^{1}$ E-mail Address: banowska@amu.edu.pl 
namely, that the world is tainted with evil, it is chaotic and irrational and, as such, could not have been made by the hand of God. However, the reality of evil, which negates the existence of the Creator and which leads to despair, is juxtaposed with the voice of inner experience, which recognizes the presence of God as love. That logical contradiction, which demands that reason transcends its own limitations, directs the thinker toward the discovery of God as an impossible but real miracle which ought to be affirmed. As he depicts the professor, Miłosz recognizes some of his own features in the portrait: the realism of experience which has its origins in sensitivity to human suffering, heroism of faith and of religious thinking, and "hunger for God" - a spiritual yearning for another dimension, which not only inspires the intellect but also stirs the imagination.

\section{CZĘŚĆ PIERWSZA: SZKIC DO PORTRETU}

Starzec, „mały staruszek o ascetycznej twarzy”, prawy i mądry profesor, wilnianin, Jego Magnificencja Rektor Uniwersytetu im. Stefana Batorego, „szacowny zabytek minionej epoki”, żałosny maniak, wizjoner niczym Kasandra wieszczący zagładę, prorok „wołający na puszczy”, boski mędrzec "zapatrzony w nurt dziejów”, postać dużego formatu, filozof rozpaczy, myśliciel anachroniczny, wybitny myśliciel chrześcijański, jeden z ostatnich myślicieli religijnych: Marian Zdziechowski. Przywołane określenia to kreski składające się na niejednoznaczny, fascynujący obraz postaci naszkicowany przez Miłosza w dwu ważnych tekstach²: eseju Religijność Zdziechowskiego z 1943 roku³ oraz wierszu Zdziechowski4, opublikowanym w tomiku poetyckim To w roku 2000. Co charakterystyczne, nazwisko profesora pojawia się w obu tytułach, silnie i jednoznacznie kierując uwagę czytelnika na głównego bohatera. Oba teksty korespondują ze sobą przez sieć wzajemnych powiązań.

Jak wskazuje tytuł eseju, perspektywą, jaką przyjmuje Miłosz w opisie myśliciela, jest religijny wymiar rozważań autora rozprawy Pesymizm, romantyzm a pod-

2 Miłosz poświęcił Zdziechowskiemu także niepublikowany „szkic o incipicie »Ziemia jest miejscem doskonałej ekstazy “ powstały ok. 1956 r., Beinecke Library”. Informację tę podaję za: A. Franaszek, Miłosz. Biografia. Znak, Kraków 2011, s. 769 (przypis 4). Pośrednio Zdziechowski jako autor eseju O okrucieństwie jest też przywoływany w wierszu Do Pani Profesor w obronie honoru kota i nie tylko (Na brzegu rzeki) oraz nawiązujących do niego, a również zamieszczonych przez Miłosza w tomie, tekstach Leszka Kołakowskiego i Jana Andrzeja Kłoczowskiego OP.

${ }^{3}$ Cz. Miłosz, Religijność Zdziechowskiego, w: Legendy nowoczesności. Wydawnictwo Literackie, Kraków 1996, s. 95-117 (wcześniej zamieszczony w tomach esejów Prywatne obowiązki, Kultura, Paryż 1972 oraz Metafizyczna pauza. Znak, Kraków 1989). Cytuję według wskazanego zbioru tekstów powstałych w okresie wojny (Legendy nowoczesności), uznając, iż są one właściwym kontekstem dla omawianego eseju.

${ }^{4}$ Cz. Miłosz, Zdziechowski, w: To. Znak, Kraków 2000, s. 62-65. 
stawy chrześcijaństwa. Świadom jednak faktu, iż Zdziechowski pozostawał postacią szerszemu gronu nieznaną 5 , zaczyna od nakreślenia krótkiej charakterystyki profesora. Wydaje się istotne, że przedstawia go najpierw nie jako autora licznych dzieł, lecz jako wykładowcę, z którym jako student miał okazję zetknąć się osobiścié.

W eseju pierwszym rysem opisu profesora jest ambiwalencja stosunku młodych wobec "małego staruszka o ascetycznej twarzy"7. Z jednej strony, był on darzony szacunkiem jako rektor, którego „nazwisko [...] otoczone było nimbem prawości i mądrości" ${ }^{\prime}$. Z drugiej - w postawie studentów nietrudno było dostrzec nutę lekceważenia, a nawet pogardy, "obcości i niezrozumienia"9 wobec "szacownego zabytku minionej epoki”, który, ich zdaniem, "nie miał pojęcia o tak zwanych problemach dnia, a jego nawoływania o niebezpieczeństwie grożącym światu ze strony komunizmu i nacjonalizmu odznaczały się zabarwieniem żałośliwie - maniakalnym"10. Po latach Miłosz dostrzega niesprawiedliwość tej oceny, sytuując ją na tle szerszego problemu sporu pokoleń, zaostrzonego przez przemiany cywilizacyjne. Źródeł niepopularności Zdziechowskiego upatruje w jego niebywałym „braku kokieterii w stosunku do młodszej generacji”11, wynikającym z faktu, iż rektor był człowiekiem dużego formatu, postacią zupełnie wyjątkową, żarliwym i bezkompromisowym wizjonerem "zapatrzonym w nurt dziejów". Niejednokrotnie wskazuje go wraz z Witkacym jako jedynych myślicieli, którzy przewidywali nadchodzącą zagładę i byli zdolni postrzegać ją w całej głębi jej duchowych znaczeń. W mroku wojennej nocy Miłosz mówi o Zdziechowskim jak o Kassandrze czy proroku „wołającym na puszczy”, widząc w nim boskiego mędrca, nieśmiertelnego przez ślad, jaki pozostawia jego myśl:

Wyobrażam sobie Zdziechowskiego, jak idzie ulicami Wilna, czytając z barokowych jak zawsze w tym mieście chmur tragedię oszalałej i skazanej ludzkości - a tuż obok orkiestra studenckiego balu gra jeszcze tango Jak pantera $w$ złotej klatce i młode istoty odby-

${ }^{5}$ Do dziś zresztą ma opinię myśliciela zapoznanego. Zob. m.in. J. Skoczyński, Pesymizm filozoficzny Mariana Zdziechowskiego. Ossolineum, Wrocław - Kraków 1983; W. Wasilewski, Marian Zdziechowski wobec myśli rosyjskiej XIX i XX wieku. Wydawnictwo Neriton, Warszawa 2005; J. Skoczyński, A. Wroński (red.), Marian Zdziechowski 1861-1938 w 70. rocznicę śmierci., Księgarnia Akademicka, Kraków 2009.

${ }^{6}$ Por. wspomnienie zamieszczone w: Czestawa Miłosza autoportret przekorny. Rozmowy przeprowadził Aleksander Fiut. Wydawnictwo Literackie, Kraków 1994, s. 219. Również matka Miłosza słuchała wcześniej wykładów Zdziechowskiego (w Krakowie) - zob. ibidem, s. 154, 413.

${ }^{7}$ Cz. Miłosz, Religijność Zdziechowskiego, w: Legendy nowoczesności. Wydawnictwo Literackie, Kraków 1996, s. 95.

8 Ibidem.

9 Ibidem, s. 96.

10 Ibidem, s. 95.

11 Ibidem, s. 97. 
wają pierwsze wtajemniczenia w sprawy [...] dramatów serca. Nie wiem, co pozostaje z balowych sukien lila, z [...] pocałunków, ze spotykania się drżących rąk. [...] Ale te [...] uczuciowe dramaty nie są, nie sposób odnaleźć ich śladu, są jednorazowe, jak ludzie, którzy ich doznali - i to przesadza spór na ich niekorzyść - a myśliciel kroczy dalej, poza granice śmierci ${ }^{12}$.

Ten jeden z ulubionych przez Miłosza obrazów - zobaczenie postaci z przeszłości idącej ulicami Wilna - powtórzy poeta w wierszu:

Oto idzie ulicą na wykład w Krakowie,

A z nim jego współcześni: tiul, aksamit, satyna

Dotykają ciała kobiet podobnych łodygom

Wymyślnych roślin secesyjnej mody.

Spojrzenia i wezwania z wnętrza nocy ${ }^{13}$.

Miłosz oddaje więc najpierw Zdziechowskiemu sprawiedliwość14 jako historiozofowi, potrafiącemu w już 1922 roku, na przekór panującym powszechnie modom intelektualnym , pisać, że „pędzimy w przepaść”15, myślicielowi, który „na rozpacz, która ogarnęła Europę w latach czterdziestych, nie potrzebował czekać ona była w nim już na wiele lat przedtem” (s. 98). Jednak to nie eschatologia autora pracy $W$ obliczu końca jest tym zagadnieniem, które do głębi zajmuje Miłosza podczas wojny i które każe powrócić mu po kilkudziesięciu latach, w innej, poetyckiej tym razem, formie, do postaci wiecznie młodego starca ${ }^{16}$.

W eseju Miłosz zaznacza, że pisząc o swoim wykładowcy chce „oddać sprawiedliwość przeszłości”, „oddać Zdziechowskiemu, co mu się należy, uiścić się z długu, jaki zaciągnęły wobec niego »dzieci« i to »straszne dzieci«"17. Skoro uczynił to już raz, dlaczego poświęca profesorowi osobny wiersz u końca wieku? Pora w tym miejscu postawić wprost pytanie o powody fascynacji myślicielem, który już w Dwudziestoleciu był traktowany - także przez Miłosza - jako "gruntownie anachroniczny"18, na domiar złego piszący stylem już wówczas uznawanym za przestarzały.

12 Ibidem, s. 100.

${ }^{13}$ Cz. Miłosz, Zdziechowski, op. cit., s. 63.

14 Por. Cz. Miłosz, Religijność Zdziechowskiego, op. cit., s. 95-96: „Dopiero potem, po latach, wielu z nich miało drogą gorzkich doświadczeń powrócić do niektórych prawd głoszonych przez Zdziechowskiego i uznać, że te same podstawy mogą się na coś przydać, choć zmieniło się «niebo historyczne»".

${ }_{15}^{15}$ Marian Zdziechowski, Europa, Rosja, Azja [Szkice polityczno-literackie], Wilno <1922>, cyt. za: ibidem, s. 98.

${ }^{16}$ Wydaje się, że Miłosz pośrednio do Zdziechowskiego właśnie odnosi zdania o "młodości prawdziwej”, którą "poznaje się po zdolności do wewnętrznych przemian, po żarliwości”. Por. Cz. Miłosz, Religijność Zdziechowskiego, op. cit., s. 98.

17 Ibidem, s. 97.

18 Ibidem, s. 111. 
Inaczej stawiając tę kwestię, jest to pytanie o powody, dla których poeta „zajmujący się niepamiętaniem" wyznaje:

A nie umiem zapomnieć jego, filozofa rozpaczy,

który zwątpił w dobroć Stworzenia.

Spośród wielu intelektualnych dróg, którymi podążał Zdziechowski, Miłosz wybiera "filozofię rozpaczy”, w znacznej mierze określającej egzystencjalne i duchowe zmagania zapisane w poetyckim tomie z przełomu wieków. Przywoływanym nurtem myślenia wszechstronnego profesora okazuje się pesymizm religijny. Dla porządku dodam, iż nie inaczej dzieje się w eseju, którego autor przyznaje: „W Zdziechowskim splatają się dwa zjawiska: pesymizm religijny i historiozoficzny katastrofizm. Pierwszym z nich chciałbym się na chwilę zająć"19. Postawionego wcześniej pytania o zasadność powrotu do Zdziechowskiego po latach nie tylko jednak ta zbieżność nie uchyla, lecz wręcz je wyostrza.

\section{CZĘŚĆ DRUGA: „NIE Z RĘKI BOGA ON WYSZEDE”}

W wierszu Miłosz buduje obraz potencjalnego spotkania "tego, który zwątpił w dobroć Stworzenia" z innym myślicielem, dla którego zło świata było jednym z centralnych problemów twórczości, Władimirem Sołowjowem ${ }^{20}$. Wśród zagadnień poruszanych podczas wspomnianej wyimaginowanej rozmowy najważniejsze wydaje się pytanie o cierpienie natury:

Prawo udręki wszystkiego co żywe

kto ustanowił tutaj na ziemi?

Do tajemnicy pochodzenia zła, odwiecznego unde malum, Miłosz próbuje się więc najpierw zbliżyć $\mathrm{z}$ perspektywy cierpienia tak wszechobecnego $\mathrm{w}$ świecie natury, że zostaje ono rozpoznane jako "prawo". Jest to temat obecny w twórczości Miłosza niemal od jej początku (mam na myśli na przykład fragmenty Pamiętnika naturalisty z Traktatu poetyckiego) po utwory późne, także towarzyszące w tomiku utworowi tu omawianemu. „Prawo udręki" wydaje się obejmować cierpienie tyleż samoistne (ból, choroby, śmierć), jak i zadane (okrucieństwo). W sposób nieunikniony wywołuje ono pytanie o to, kto je ustanowił. Pytanie o Sprawcę to pytanie o Stwórcę: o to, jak to możliwe, by istniało zło w świecie stworzonym przez dobrego Boga? Pytanie to pozostaje zawieszone; pewną formą odpowiedzi jest

\footnotetext{
19 Ibidem, s. 100.

${ }^{20}$ Zdziechowski widział w nim mistyka, ascetę i proroka. Por. M. Zdziechowski, Pesymizm, romantyzm a podstawy chrześcijaństwa. Warszawa 1993, t. 1, s. 316.
} 
przytoczenie fragmentu rozważań Zdziechowskiego, tak jakby poeta ponownie jemu oddawał głos:

Zachowałem dotychczas jego słowa: „I w miarę lat, im dalej w życie i w świat szedłem, tym wyraźniej i boleśniej uświadamiałem sobie, że świat ten, gdy go myślą, jako całość objąć, bezładem jest i bezrozumem, nie zaś, jak nas uczą, dziełem rozumu: nie z ręki Boga on wyszedl."

Cytat ten pochodzi z książki Zdziechowskiego Pesymizm, romantyzm a podstawy chrześcijaństwa, co Miłosz zaznacza w notce zamieszczonej pod wierszem. Uderzające, iż jest to cytat zamieszczony już wcześniej w eseju²1. Musiał więc być on dla Miłosza szczególnie ważny. $\mathrm{W}$ roku pisania wiersza o starym profesorze niemal osiemdziesięcioletni Miłosz mógłby za własne przyjąć słowa wprowadzające główną myśl: „I w miarę lat, im dalej w życie i w świat szedłem”, a także następne: "tym wyraźniej i boleśniej uświadamiałem sobie". Jasna i bolesna świadomość jest porażającą cechą tego tomiku, choć trzeźwość myślenia pozbawionego iluzji cenił Miłosz już znacznie wcześniej22.

Dalsza, i centralna, część tekstu Zdziechowskiego przytoczonego w wierszu przez Miłosza nasuwa więcej komplikacji. Dotyczy ona rozpoznania świata jako bezładu i bezrozumu. Zły świat nie mógł być dziełem dobrego i rozumnego Boga: stąd „nie z ręki Boga on wyszedł”. U źródeł tego przeświadczenia leży tajemnica zła, podważająca dobro, ład i rozumność Stworzenia:

pozostaje nam [...] przypuścić, że świat cały myśli i badaniu naszemu dostępny uwikłany został w jakąś pierwotną a straszną katastrofę, że sam pryncyp jego bytu, ta substancja powszechna, którą prościej

D u s zą św i a ta nazwać, odpadła od Boga i że wraz z nią odpadliśmy i my. Czyli zło nie jest, jak nauczali optymiści chrześcijańscy, czymś drobnym i przypadkowym, $[\ldots]$ ale jest, stało się naturą rzeczy. $[\ldots]^{23}$

Zdziechowski odrzuca tym samym jako niewystarczającą naukę św. Augustyna, postrzegającą zło jedynie negatywnie, jako nie-byt, „brak” (dobra), koncepcję odmawiającą mu substancji. Dostrzega również w tej doktrynie początek negacji pesymizmu oraz obwinia ją o zapoznanie pierwotnie obecnej w chrześcijaństwie, a wyrażonej w Ewangelii świętego Jana, prawdy o tym, że "świat w złym leży”. Do intuicji tej miała powrócić myśl chrześcijańska (lub chrześcijaństwem inspirowana)

${ }^{21}$ Miłosz zamieścił ten cytat również we wspomnianym niepublikowanym szkicu o incipicie »Ziemia jest miejscem doskonałej ekstazy«. Por. A. Franaszek, Miłosz. Biografia, op. cit., s. 105.

22 Por. rozważania zamieszczone w eseju Rzeczywistość (Cz. Miłosz, Rzeczywistość, w: Ogród nauk, Lublin 1986, s. 32) uderzająco zbieżne z przemyśleniami Zdziechowskiego z jego książki Pesymizm, romantyzm a podstawy chrześcijaństwa (Por. M. Zdziechowski, Pesymizm, romantyzm a podstawy chrześcijaństwa, op. cit., t. 2, s. 398).

${ }^{23}$ M. Zdziechowski, Pesymizm, romantyzm a podstawy chrześcijaństwa, op. cit., t. 2, s. 403. 
dopiero w wieku XIX, paradoksalnie także pod wpływem niechętnego judaizmowi i chrześcijaństwu Schopenhauera, dzięki dokonanemu przez niego bliższemu zaznajomieniu Europy z filozofią Wschodu (zwłaszcza buddyzmem i brahminizmem). Za prekursorów asymilacji pesymizmu $w$ obręb myśli chrześcijańskiej uznaje Zdziechowski Schellinga z drugiego okresu twórczości ${ }^{24}$, niemal nieznanego szwajcarskiego myśliciela francuskojęzycznego Charlesa Secrétana oraz Władimira Sołowjowa ${ }^{25}$.

Dla poszukiwań Zdziechowskiego oraz podążającego śladem jego myśli Miłosza najważniejsze są próby zmierzenia się z genezą zła podjęte przez Secrétana i Sołowjowa. Secrétan odrzucił Schellingiańską koncepcję "natury w Bogu” jako pierwiastka ograniczającego niczym nie ograniczonego Boga oraz przypisującą $\mathrm{Mu}$ możliwość czynienia zła. Zaproponował rozwiązanie, według którego substancję Boga stanowi wola,

więc wszystko, co istnieje, powstało z woli Boga [...] wola przeto jest także substancją świata, czyli, innymi słowy, stworzenie wyszło z rąk Stwórcy substancjonalnie z nim jednakie, a zatem wolne. Będąc wolne, może ono do Stwórcy swojego się wznieść i z nim połączyć, może też od niego odpaść. To drugie jest źródłem złego. I to drugie właśnie się stało; stworzenie odpadło od Stwórcy ${ }^{26}$.

Cytując oryginalne pojęcie Secrétana - Créature autor Pesymizmu pozostawia je, jak chciał szwajcarski filozof, zapisane wielką literą. W wierszu Miłosza Zdziechowski określony zostaje jako ten, „który zwątpił w dobroć Stworzenia”, zapisanego również $w$ ten sam sposób. Szczegół ten wydaje się o tyle istotny, iż przez Stworzenie rozumie Secrétan nie poszczególne byty stworzone, lecz Jedność istniejącą przed podziałem czy wyodrębnieniem bytów jednostkowych, „istotę odrębną, zaród wszystkiego, co jest”27, pierwotną siłę kształtującą, inaczej mówiąc, „wolę

${ }^{24}$ Spośród propozycji Schellinga najistotniejsza dla Zdziechowskiego wydaje się idea „natury w Bogu" oraz stanowiąca jej rozwinięcie koncepcja wyróżnienia duszy świata i boskiej Sofii. Jak komentuje Jan Skoczyński, Schelling dokonał „metafizycznego rozróżnienia między tym, c z y m jest każdy byt, a tym skąd się wywodzi. W sposób szczególny dotyczy ono Boga, obok którego pojawia się "natura w Bogu«, różna od niego samego podstawa i warunek istnienia świata”. Z kolei w "naturze w Bogu” dokonał Schelling wyodrębnienia „dwu sił: żywotności zwanej przez niego duszą świata i mądrości - boskiej Sofii, ku której świat zmierza, będącej jego najdoskonalszym kształtem i pośredniczką między Bogiem i stworzeniem. [...] Ścieranie się tych dwu sił prowadzi naturę do doskonałości i jedności z Bogiem. [...] Źródło zła leży [...] w afirmacji samej siebie przez »naturę w Bogu«, zło zaś nie jest niebytem [...], lecz bytem nieprawdziwym, mimo to rzeczywistym i strasznym w swych przejawach i skutkach". Por. J. Skoczyński, Pesymizm filozoficzny Mariana Zdziechowskiego, op. cit., s. 33-34.

${ }^{25} \mathrm{Na}$ temat filozoficznych źródeł pesymizmu Zdziechowskiego zob. J. Skoczyński, Filozofia i religia, w: Pesymizm filozoficzny Mariana Zdziechowskiego, op. cit., s. 31-48.

${ }^{26}$ M. Zdziechowski, Pesymizm, romantyzm a podstawy chrześcijaństwa, op. cit., t. 1, s. 273 (cytując z pism M. Zdziechowskiego, uwspółcześniam pisownię).

27 Por. ibidem. 273. 
stworzoną" będącą wolnym tworem Boga. Nazwał ją Secrétan „duszą", jej odpowiednikiem - do pewnego stopnia - będzie w koncepcji Sołowjowa "dusza świata"28. Stworzenie upadło, odłączając się od Boga, a ów bunt uznaje Secrétan za fakt metafizyczny, poprzedzający nie tylko narodziny pierwszego człowieka, lecz w ogóle powstanie świata materialnego ${ }^{29}$. Oznacza to, że wszystko, co istnieje, jest naznaczone konsekwencją upadku, czyli złem w jego różnych postaciach: cierpienia, bólu, okrucieństwa czy zła moralnego:

Wraz z upadkiem Créature oderwało się od Boga wszystko od niej pochodzące, wszechświat cały; w złem zatopieni jesteśmy wszyscy, zło jest treścią bytu ${ }^{30}$.

Człowiek rozpoznaje siebie jako część Stworzenia także przez to, iż konsekwencje upadku naznaczają jego wewnętrzną rzeczywistość:

Upadek, to hipoteza, której nie można nie przyjać, jeżeli zrozumieć i wytłumaczyć zechcemy naszą własną obrzydliwość. [...] upadek pierwszego stworzenia jest naszym własnym upadkiem, albowiem pierwsze Stworzenie, ta pierwsza istota, przez która i w której katastrofa się dokonała - to my sami. [...] jesteśmy winni od urodzenia, to znaczy, że zgrzeszyliśmy, zanim przyszliśmy na świat ${ }^{31}$.

Wyłonienie form poszczególnych było odpowiedzią Boga na podejmowane przez Stworzenie próby powrotu do Stwórcy, a uwieńczeniem tego procesu było stworzenie ludzkości. Rozumiał ją Secrétan „nie tylko jako wcielenie jednostek, lecz przede wszystkim jako jedność, jako ideę, jako istotę metafizyczną32", a jej symbolicznym uosobieniem był prarodzic Adam. Stanął on ponownie przed szansą przylgnięcia do Boga, czyli przebóstwienia woli, lecz zamiast tego powtórzył grzech odpadnięcia od Boga. Upadek człowieka jako istoty świadomej okazał się brzemienny w skutkach: odtąd zło naznacza nie tylko świat natury, lecz także specyficznie ludzki świat historii.

Jeszcze inne rozwiązanie problemu dobroci Stwórcy i zła stworzenia zaproponował przywoływany w wierszu Miłosza Władimir Sołowjow. Powstanie świata postrzeganego jako „bezład i bezrozum”, który „nie z ręki Boga [...] wyszedł” rosyjski myśliciel proponuje wyjaśnić przez wprowadzenie istoty pośredniej między Bogiem a światem. "Jest nią dusza świata, boska S of i a (Mądrość), która, będąc bezpośrednią manifestacją Boga, boska jest $\mathrm{w}$ substancji swojej i stanowi zarazem substancję świata" 33 . W swoich wczesnych pismach - Wykładach o bożo-

28 Por. ibidem, s. 292.

29 Por. ibidem, s. 273.

${ }^{30}$ Ibidem, s. 274.

${ }^{31}$ Ibidem, s. 293.

32 Ibidem, s. 292.

33 Ibidem, s. 327. Na temat swoistej interpretacji Sołowjowa przez Zdziechowskiego zob. W. Wasilewski, Marian Zdziechowski wobec myśli rosyjskiej XIX i XX wieku, op. cit., rozdz. III i IV. 
człowieczeństwie - źródła zła upatrywał Sołowjow w odpadnięciu Sofii od Boga. By jednak uniknąć sprzeczności wynikającej z faktu, iż z Mądrości Boga mógł wyłonić się „świat, który w złym leży”, w jednym ze swoich późnych studiów - La Russie et L'Eglise universelle rozdwoił ją na Sofię w ścisłym znaczeniu i na Duszę świata. Sofia w ścisłym znaczeniu byłaby pierwotnie stworzonym pierwiastkiem duchowym, a dusza świata - pierwiastkiem materialnym ${ }^{34}$. Boska Sofia upaść nie mogła, natomiast dusza świata nie była istotą żywą, lecz jedynie materiałem, pozbawionym woli oraz świadomości i jako taka również upaść, czyli zgrzeszyć, nie mogła. W związku z tym Sołowjow, pragnący pierwotnie oddzielić duszę świata od Stwórcy, musiał jednak przenieść ją w głąb Boga i - jak pisze Zdziechowski -

określić jako zawartą w Bogu możliwość zła, czyli chaosu. Możliwość zaś chaosu staje się rzeczywistością z chwilą, gdy Bóg Ojciec wstrzymuje się od reagowania przeciw możliwości tej i tym samym dopuszcza rozpętanie chaotycznych pierwiastków istnienia. Świat więc [...] powstał u Sołowjowa i Schellinga nie z pozytywnego aktu Boga ${ }^{35}$.

Świat pogrążony $\mathrm{w}$ chaosie wymaga naprawy, to wniosek wszystkich trzech przywoływanych tu myślicieli, najsilniej jednak obecny właśnie w twórczości Sołowjowa. Odkupienie przynosi Słowo wcielone, Logos, Chrystus. Wywiązuje się walka o duszę świata, która jest tym trudniejsza, że Stworzenie musi zmagać się nie tylko ze swą zranioną, grzeszną istotą, lecz że zaangażowane są $\mathrm{w}$ nią także demoniczne moce zła. Kresem tej walki będzie bożoczłowieczeństwo, cel historii ${ }^{36}$. Osiągnięcie tego celu przez ludzkość wydaje się jednak dość odległe. Pogłosem koncepcji zmagań o duszę świata jest $\mathrm{w}$ wierszu dwuwers ${ }^{37}$ :

34 Por. ibidem, s. 327-333.

35 Ibidem, s. 336-337.

${ }^{36}$ Por. omówienie rozważań Sołowjowa przez Zdziechowskiego, ibidem, s. 340: „Słowo Boże światłem miłości i łaski obejmuje Duszę świata, jednak moc chaosu jest wielka, tym większa i groźniejsza, że ma sprzymierzeńca w mocach szatańskich [...] Między niebem a piekłem [...] stacza się walka o posiadanie Duszy świata. [...] Powoli Logos bierze górę nad ciemnością [...] koroną kosmogonicznego procesu jest człowiek. [...] Nosi on Boga w sobie, [...] ale tę boską substancję chce on mieć nie od Boga tylko, lecz i od siebie - i utwierdzając się poza Bogiem, odpada od Boga. [...] Pierwiastek zła występuje odtąd w nowej postaci, w postaci wolnych i świadomych czynów człowieka. W zniszczeniu tego pierwiastka objawia się idea historii. Jej treścią jest walka ze złem i grzechem [...] w chwili stosownej Słowo daje Duszy świata, z nią się łącząc, to, czego ona pragnie i do czego dąży, czyli pełnię bytu, która objawia się w postaci Chrystusa, Boga i człowieka. [...] Odtąd Bożoczłowieczeństwo jest celem historii".

37 We fragmencie tym obecne jest wspomnienie pierwotnej katastrofy, buntu Lucyfera, który przyczynił się do pierwszego Upadku, naznaczającego Stworzenie złem. Walka ta nie została jednak zakończona, trwa nadal i toczy się zarówno w obrębie świata natury, jak i historii. Określenie „Książę Rebelii” w swoim podstawowym sensie odnosi się do przywódcy demonów, jednak słowo "rebelia”, oznaczające tyleż „bunt”, co i „rewolucję”, przywołuje również kontekst historyczny. Wydaje się, że Miłosz, niezależnie od prowadzenia wątku poświęconego genezie i istocie zła, czyni w tym miejscu także dyskretną aluzję do licznych rozważań Mariana Zdziechowskiego na temat zagrożeń płynących 
W kosmicznej bitwie błyskają miecze aniołów.

Książę Rebelii naciera, cofają się słudzy jasności.

„Książę Rebelii” przywołuje także inne określenie szatana - „książę tego świata", mówiące o poddaniu doczesności władzy mocy piekielnych:

Okrucieństwo, kamienne,

Jak inaczej tłumaczyć? Choć on, profesor,

Nie mógł mówić wyraźnie, że wierzy w diabelskość świata.

W swoim wierszu - portrecie Miłosz operuje grą zbliżeń i oddaleń. Między dwoma sąsiadującymi ze sobą, cytowanymi tu, fragmentami wiersza nietrudno wysłyszeć różnicę stylu. Wysoki, patetyczny w wersach o „kosmicznej bitwie aniołów", w następnych - ulega obniżeniu. Wydaje się, że styl pierwszy jest, poza wszystkim, znakiem pewnego dystansu czy oddalenia, drugi - zbliżenia do poglądów Zdziechowskiego.

„On, profesor" - słowa te odnosić się mogą tyleż do autora Pesymizmu..., co i samego Miłosza, tak jakby poeta zbliżał się w tym miejscu do liryki maski. Jak zawsze w takim przypadku, to nie więcej niż możliwość, domniemanie, które jednak zdaje się potwierdzać kilka tropów. O pierwszym, najbardziej się narzucającym - tj. tożsamości profesji, już wspomniałam. Na następny nakierowują słowa: „nie mógł mówić wyraźnie”. Patronami wizji poety, który ujawnia tylko część prawd, a o niektórych mówi jedynie milcząc, poety piszącego szyfrem patronują Mickiewicz (jako autor Stopni prawd) i Oskar Miłosz jako dwa równoległe źródła inspiracji. Wizja ta jest silnie obecna w całym tomie. Najpierw, tom ten otwiera: inicjalny wiersz To od takiego wyznania właśnie się zaczyna: „Żebym wreszcie powiedzieć mógł, co siedzi we mnie [...]". Zaznacza się także w innych wierszach, między innymi w Przemilczanych strefach, Przepisie czy Texasie. Obraz profesora literata, który "nie mógł mówić wyraźnie” pokrewny jest obrazowi bohatera z wiersza To jasne, który "nie mówił, co naprawdę myśli”:

To jasne, że nie mówiłem, co naprawdę myślę

Ponieważ na szacunek zasługują śmiertelni [...]

Pisanie polegające na jednoczesnym zasłanianiu i odkrywaniu opiera się na metodzie „zacierania śladów”: „Pisanie było dla mnie ochronną strategią/ Zacie-

dla Europy ze strony komunizmu („rebelia” październikowa) i hitleryzmu. Filozof ujmował je w kategoriach eschatologicznych, dostrzegając w nich niebezpieczeństwo zniszczenia podstaw kultury europejskiej o takiej sile, iż widział w nich - poza czysto ludzkimi determinantami - również ingerencję mocy demonicznych. Jak widać, jego rozmyślania na temat zła nie miały charakteru wyłącznie abstrakcyjnych spekulacji, myśliciel widział w nich swoiste narzędzie do rozpoznawania „znaków czasu". Kosmiczna bitwa aniołów" trwa więc nadal, a zło wydaje się tak wszechobecne, iż nasuwa myśl o „wycofaniu” ze świata aniołów Bożych, zdają się oni w tej walce przegrywać. 
rania śladów" (To). Jest to metoda właściwa dla tego, kto dotyka tabu: „Bo nie może podobać się ludziom/ Ten, kto sięga po zabronione" (To).

Samotność poety, który „nie może podobać się ludziom” pokrewna jest - to trzeci ślad ustanawianej między Miłoszem a Zdziechowskim bliskości - osobności starego profesora "samotnego na ich święcie barwy i dotyku”.

$\mathrm{Na}$ ślad czwarty naprowadza określenie „okrucieństwo, kamienne”, dla którego istotnym motywem wydaje się "diabelskość” świata. Na kwestię okrucieństwa $^{38}$ Zdziechowski wyczulony był szczególnie - jako autor eseju O okrucieństwie ${ }^{39}$, niebywałego, żarliwego, radykalnego. Nie przypadkiem zostaje ono w wierszu Miłosza określone jako „kamienne”. W wierszu tytułowym omawianego tomu „TO” przyrównane zostaje do „kamiennego muru”. „TO” opisywane jest jedynie przez przybliżenia, porównania, analogie. Przywoływane sytuacje - bezdomnego w nieznanym, mroźnym mieście, Żyda osaczonego przez niemieckich żandarmów, nieuleczalnie chorego czy żałobnika - ukazują widzenie bez iluzji, w prawdzie, która odsłania „nędzę, chorobę, starzenie się i śmierć” jako determinanty ludzkiego losu. „TO” można więc odczytywać jako zrodzoną z doświadczenia śmierci świadomość rządzącego światem prawa konieczności:

Ponieważ TO oznacza natknięcie się na kamienny mur

I zrozumienie, że ten mur nie ustąpi żadnym naszym błaganiom.

Wszechobecność zła, wraz z jedną z jego odmian - nieuchronnością śmierci ujawnia zarazem zasadniczą obcość kamiennego świata:

Świat jest nieugięty, nieubłagany, obojętny.

To kamień, o który, biegnąc boso, raniłeś wielki palec stopy. [...]

(Przeciwieństwo)

Świat jak kamienny mur - to metafora powracająca w wielu utworach tomiku, ważna dla zrozumienia relacji między światem ludzkim a porządkiem natury i historii.

\section{CZĘŚĆ TRZECIA: "ŚWIAT JEST IRRACJONALNY. BÓG JEST CUDEM"}

Podsumowując dotychczasowe rozważania Zdziechowskiego przywoływane w wierszu Miłosza, można stwierdzić, iż do kwestii fundamentalnej, tj. do uznania

\footnotetext{
38 Por. ibidem, t. 2, s. 404: „w pesymizmie przedmiotowa o b se rw a cja życia pogłębioną zostaje o dczu ciem zła, które w postaci walki wszystkich przeciw wszystkim objęło świat. Walki tej najstraszniejszym objawem - okrucieństwo".

${ }^{39}$ M. Zdziechowski, O okrucieństwie, Kraków 1928.
} 
świata za bezład i bezrozum, którego Stwórcą nie mógł być dobry Bóg, doprowadziło filozofa odkrycie wszechobecności zła w naturze i w historii. Ogrom cierpienia, którego kulminacją jest okrucieństwo, zdaje się nieuchronnie nasuwać myśl o diabelskości świata. Krokiem następnym jest podważenie istnienia Boga.

"Nie ma Boga - głosem wielkim wołają i natura, i historia" - od takich słów rozpoczyna się drugi z obszernych (jak na wiersz) cytatów z książki Zdziechowskiego. Myśliciel był świadom, że filozofia pesymizmu może w pierwszym odruchu doprowadzić do negacji Boga, byłby to poprawny, logicznie wyciągnięty wniosek płynący z rozumowania opartego na obserwacji i doświadczeniu. Miłosz przytacza w eseju słowa Zdziechowskiego, który w swoim szkicu pisał:

Rozmyślania nad zagadnieniem religii doprowadzały mnie zawsze i tak samo utwierdzają dziś we wniosku, że wiara jest gwałtem zadanym rozumowi; zbyt głośno to, co się na świecie dzieje, świadczy, krzyczy przeciw Bogu ${ }^{40}$.

Miłosz zwraca uwagę na „przekonanie o bezrozumności wiary - a nawet więcej - o niemożności pogodzenia wiary z poczuciem etycznym" ${ }^{\prime 1}$, dostrzegając $\mathrm{w}$ tym przekonaniu ślad pokrewieństwa autora Pesymizmu... z modernizmem katolickim ${ }^{42}$. Sam Zdziechowski, choć „nie wykroczył jawnie poza naukę Kościoła"43, to niejednokrotnie bliskość tę podkreślał"4. Omawiając stosunek Zdziechowskiego wobec modernistów, Miłosz podkreśla, iż bliscy byli mu przede wszystkim w irracjonalizmie poznania oraz "gdy usiłowali zastąpić Boga nadświatowego Bogiem immanentnym"45. Miłosz dystansuje się zarówno wobec modernistycznych napaści na rozum ${ }^{46}$, jak i wobec wynikającej stąd, a mogącej grozić fideizmem, "religii serca" 47 . Obce jest mu samo tak ostre przeciwstawianie wiary rozumowi, a rzekomy konflikt między nimi postrzega jako zjawisko czasowe, jedną $\mathrm{z}$ faz kultury, mającą swe źródło w oświeceniowych z proweniencji uroszczeniach rozumu, fazę, dodajmy, przemijającą, której kresem może stać się wyciagnięcie

${ }^{40}$ M. Zdziechowski, O okrucieństwie; cyt. za: Cz. Miłosz, Religijność Zdziechowskiego, op. cit., s. 104.

${ }^{41}$ Cz. Miłosz, Religijność Zdziechowskiego, op. cit., s. 105.

${ }^{42}$ Stosunek Zdziechowskiego wobec modernizmu to osobny, złożony problem, który jedynie tutaj sygnalizuję. Zob. J. Skoczyński, Religijny modernizm Zdziechowskiego, w: Pesymizm filozoficzny Mariana Zdziechowskiego, op. cit., s. 48-57.

${ }^{43}$ Cz. Miłosz, Religijność Zdziechowskiego, op. cit., s. 107.

${ }^{44}$ Za dowód pośredni niech posłuży tom drugi jego rozprawy o pesymizmie, niemal w całości poświęcony modernistom, za mistrza których uważał nota bene Secrétana. Wśród wielu ich zasług niebagatelną rolę przypisywał Zdziechowski temu, iż (podążając inną drogą niż filozofia) oni również dokonali asymilacji pesymizmu w obręb myśli chrześcijańskiej.

${ }^{45}$ Ibidem, s. 106.

${ }^{46}$ Nie przypadkiem w wierszu niemal poprzedzającym Zdziechowskiego w układzie tomiku pada zdanie: „Rozum jest wielkim boskim darem”. Por. Cz. Miłosz, Czego nauczyłem się od Jeanne Hersch? W: To, op. cit., s. 59.

47 Por. Cz. Milosz, Religijność Zdziechowskiego, op. cit., s. 106. 
wniosków z najnowszych odkryć nauki (o czym pisał o tym w Ziemi Ulro). Nie te kwestie okazują się więc decydujące dla przypominania postaci Zdziechowskiego.

Wspomniany irracjonalizm poznania, więcej nawet - irracjonalność świata, silnie zaznacza się w dalszej części przytaczanej w wierszu Miłosza wypowiedzi Zdziechowskiego:

Nie ma Boga - głosem wielkim wołają i natura, i historia... ale głos ten ginie w harmonii psalmów i hymnów, w tym wielkim, odwiecznym, z najgłębszych głębin ducha idącym wyznaniu, iż jako »ziemia bez wody « jest dusza człowieka poza Bogiem. Bóg jest. Tylko fakt istnienia Boga to cos przekraczającego zakres myśli światem zewnętrznym zajętej, to cud. Le monde est irrationnel. Dieu est un miracle.

Fragment ten, będący dalszą częścią zamieszczonego w wierszu wcześniej cytatu, (zaczynającego się od słów „Im dalej w życie i w świat szedłem...), pochodzi z Przedmowy Zdziechowskiego do jego opus magnum. Dwa ostatnie zdania zostały zachowane $\mathrm{w}$ języku francuskim jako cytat z Secrétana ${ }^{48}$. Patronują one nota bene jako motto całej rozprawie Zdziechowskiego.

Głosowi natury i historii, głosowi cierpienia i zła, z którego dla ateisty wynika konieczność pesymizmu absolutnego, przeczącego istnieniu Boga, przeciwstawiony zostaje jednak inny głos. Bywa on określany jako głos bądź potrzeba serca, głos sumienia, głos tęsknoty za Bogiem, głos niepokoju czy też głos doświadczenia wewnętrznego. Jak pisze Miłosz w swoim eseju o Zdziechowskim, "głos tęsknoty do Bóstwa, który w sobie słyszał, był dla niego głosem nadziei przeciwko nadziei, pragnieniem cudu"49. Jest zatem rzeczywistość zła, w świetle rozumu i wrażliwości negująca istnienie Boga, i jest Bóg, o którym świadczy sumienie, a który objawił się jako miłość. To logicznie niemożliwe, to sprzeczność. „Nie, to nie sprzeczność, to coś, co przekracza granice umysłu naszego" ${ }^{50}$. To cud - odpowiada omawiający rozważania Secrétana Zdziechowski ${ }^{51}$.

${ }^{48}$ Wydaje się ważne, iż słowa te podaje Zdziechowski jako własne, niejako się pod nimi podpisując, choć są one wynikiem zamieszczonych we wnętrzu rozprawy rozważań poświęconych filozofii Charlesa Secrétana. Dowodzi to utożsamienia czy przynajmniej bliskości rozumowania obu myślicieli. W dalszej części Przedmowy jej autor wyznaje już wprost: „Nie znałem Secrétana [...] jednak tak, jak on, czułem i rozumowałem, gdy, walcząc $\mathrm{z}$ wątpieniem i przeciw wnioskom myśli ratując wiarę [...] stawiałem [...] na wskroś antyteologiczne twierdzenie, że wiara jest gwałtem zadanym rozumowi. Tak rozumując, szedłem dalej, niż «modernizm» [...], dalej, niż nieznany mi wówczas [...] wielki kardynał Newman, który nie wahając się wyznać, że nie dostrzegał w świecie odbicia jego Stwórcy, przenosił wiarę ze sfery rozumu w sferę sumienia i kreśląc granicę między rozumem pozostawionym samemu sobie, a rozumem oświeconym Łaską, wygłaszał, iż »chcieć narzucać ludziom wiarę z pomocą argumentów jest takąż samą niedorzecznością, jak ją narzucać z pomocą tortur «". Por. M. Zdziechowski, Pesymizm, romantyzm a podstawy chrześcijaństwa, op. cit., t. 1, s. XIII.

${ }^{49}$ Cz. Miłosz, Religijność Zdziechowskiego, op. cit., s. 108.

${ }^{50}$ M. Zdziechowski, Pesymizm, romantyzm a podstawy chrześcijaństwa, op. cit., t. 1, s. 285.

${ }^{51}$ Streszczam w tym miejscu wywody Zdziechowskiego poświęcone Secrétanowi. Por. ibidem, s. $275-294$. 
Zło uprawniałoby do wniosku, że „świat jest dziełem niepojętego trafu, czyli, po prostu, nonsensem. Ale sumienie woła, że Bóg jest - i serce odnosi tu łatwy triumf nad rozsądkiem" ${ }^{52}$. Serce pragnie cudu, i pragnienie to uznaje Zdziechowski za pośredni dowód jego prawdziwości, niezależnie od logicznej niemożliwości jej dowiedzenia, a nawet wbrew niej. I dodaje, cytując Secrétana: „należy [... ten cud - LB] afirmować" 53 .

Zdziechowski zdaje się więc skłaniać ku twierdzeniu, iż niepojęty świat może być przez człowieka zrozumiany i przyjęty jedynie przez rozum oświecony łaską wiary, która umożliwia przeskok nad niemożliwym, przekroczenie rozumu w jego ograniczeniach:

„świat jest irracjonalny". Rozum nasz wytłumaczyć go nie jest w stanie, „trzeba się wznieść poza rozum, ażeby go wytłumaczyć" 54 .

świat jest irracjonalny $[\ldots]$ jest bezrozumny i świadczy przeciwko Bogu - i ze stanowiska świata Bóg jest niemożliwością, c u d e m, jednak w ten cud wierzymy, bośmy się $\mathrm{z}$ nim bezpośrednio zetknęli [...]. Ale nie $\mathrm{w}$ istocie swojej irracjonalnym jest świat, lecz w wyobrażeniu naszym, jako zjawisko, na które patrzymy, które badamy; w istocie swojej jest on ponad rozumem i aby go poznać, rozum przekroczyć musi swoją własną granicę $[\ldots]^{55}$.

To przekroczenie dokonuje się między innymi w odkryciu, iż pierwotnie świat został stworzony przez Boga z miłości, w której objawia On swoją istotę. Do tego "logicznego rozwiązania zagadki świata” doszedł Secrétan przez uznanie, iż dla absolutnie wolnego Boga, którego wola wyraża się w akcie (czynie), nie istniała żadna inna przyczyna stworzenia (która gdyby zaistniała, np. w postaci Jego potrzeby, to znaczyłoby to, iż byłby on przez nią ograniczony) niż miłość. Innymi słowy, absolutnie wolny Bóg stworzył wolne stworzenie nie dla siebie, lecz z miłości do niego. „Przez miłość - puentuje Zdziechowski rozważania Secrétana - Bóg objawia się i ogłasza Bogiem" ${ }^{\prime 56}$. I dodaje:

Więc skądże miłość Boga do nas? „Bóg nas kocha, bo kocha, oto wszystko”. [...] Bóg miłość jest czymś niepojętym, to cud; i istnienie Boga staje się wiekuistym cudem, a cud ten jest podstawą wszystkiego, co znamy, czym jesteśmy ${ }^{57}$.

Secrétan, a z nim i Zdziechowski, jest świadom, iż uznanie pragnienia cudu jako podstawy rozpoznań na temat Boga i świata jest propozycją, która z czysto logicznego punktu widzenia oznacza rodzaj kapitulacji:

\footnotetext{
52 Ibidem, s. 276.

53 Ibidem, s. 285.

54 Ibidem, s. 288.

55 Ibidem, s. XV.

56 Ibidem, s. 287.

57 Ibidem, s. 288.
} 
"Cud - oto wynik naszego szukania Absolutu. Biorąc miłość za punkt wyjścia do wszelkich tłumaczeń świata, my przecinamy węzeł, a nie rozwiązujemy. Dieu est un miracle" 58 .

Komentując dorobek autora Filozofii wolności Zdziechowski podsumowuje:

I choć Secrétan nigdzie wyraźnie tego nie wygłosił, jednak całe jego przedstawienie rozwoju filozofii zdawało się być skierowane ku wykazaniu nadzwyczajnej trudności żywej wiary w żywego Boga ${ }^{59}$.

Cóż wobec tego może być odpowiedzią na tajemnicę, ów gordyjski węzeł nierozwiązywalny? Jedną ze wskazówek zawiera przytaczana już wcześniej myśl, iż "cud należy afirmować". Zdziechowski idzie jeszcze dalej i mówi o konieczności adoracji. Wobec sfery tajemnic - pisze -

jedyną możliwą dla człowieka postawą jest milczenie i adoracja - adoracja, która Secrétanowi wyrwała z ust słowa Dieu est un miracle ${ }^{60}$.

Postawa ta wyraża się w modlitwie. Inaczej mówiąc, odpowiedzią człowieka na rzeczywistość Boga pojętego jako cud jest „cud wierności prochu”:

Tylko dźwięk dzwonów,

Tylko jarzenie monstrancji,

Głosy śmiertelne ogłaszające chwałę,

U Dominikanów i Franciszkanów

Posadzki wytarte stopami pokoleń

Chronią nas. Nawet jeżeli złudzenie

Łączy nas wiarą $\mathrm{w}$ nieśmiertelne trwanie,

Dzięki czynimy, proch, za cud wierności prochu.

Obok głosu cierpiącej natury, głosu okrucieństw historii, głosu całego - niewyczerpalnego w opisie - zła świata wybrzmiewa głos wewnętrzny człowieka spragnionego Boga, głos wyrażający się w "głosach śmiertelnych ogłaszających chwałę". Paradoks dobrego Stwórcy i złego świata, uchylony przez rozpoznanie Boga i świata jako cudu, osiąga swą kulminację w modlitwach uwielbienia i dziękczynienia, w postawie zaufania (niewolnego zresztą od zwątpień). To ona "chroni" przed bezmiarem rozpaczy, to ona odkrywa sens nadziei i umożliwia "afirmację wszystkiego, co Bożym jest w tym świecie i życiu"61.

Tak jak uprzednio wiara umożliwiała przekroczenie ograniczeń rozumu, tak modlitwa - jako jej wyraz - okazuje się siłą przezwyciężającą rozpacz. Pesymizm

\footnotetext{
58 Ibidem, s. 293-294.

59 Ibidem, s. 280.

60 Ibidem, s. 337.

${ }^{61}$ Ibidem, t. 2, s. 3.
} 
zasymilowany przez chrześcijaństwo odsłania się zatem w ujęciu Zdziechowskiego jako pesymizm względny, korygowany przez paradoksalne rozpoznanie i afirmację miłości Boga. Jak trafnie zauważa Jan Skoczyński,

Pesymizm jest wiec dla niego etapem rozwoju świadomości od negacji do afirmacji losu człowieka, ze wszystkimi jego przypadłościami, i próbą nadania mu głębszego sensu $^{62}$.

\section{CZĘŚĆ CZWARTA: „OSTATNI MYŚLICIEL RELIGIJNY”}

Myliłby się jednak ten, kto by sądził, iż wspomniana afirmacja losu człowieka niweluje ból. Dobitnie potwierdza to Miłosz w swoim wierszu, w którym do profesora, dotąd występującego $\mathrm{w}$ roli bohatera trzecioosobowego, zwraca się poeta bezpośrednio:

Nieubłagany ciąg zagłady i narodzin, Magnificencjo.

Długo trwała moja nauka powściągania siebie.

Bardziej od Ciebie przebiegły, poznawałem moje stulecie, udając,

Że znam sposób i zapominam o bólu

Ból, bardzo ważny motyw całego tomu, spaja klamrą ten wiersz - portret, wiersz - rozmowę ze starym profesorem, z filozofami XIX wieku, z modernistami katolickimi wreszcie; od bólu się zaczyna i na bólu kończy. I to ból właśnie okazuje się powodem, dla którego poeta nie umie "zapomnieć jego, filozofa rozpaczy”. Bólowi doświadczanemu w wymiarze egzystencjalnym odpowiada w sferze intelektualnej filozofia pesymizmu, ważna dla Miłosza już od lat młodzieńczych ${ }^{63}$.

To tutaj znajduje się odpowiedź na pytanie, dlaczego mimo zaznaczonych pokrótce rozbieżności między nim a Zdziechowskim, powraca Miłosz po latach do zapoznanego myśliciela. Ceni go przede wszystkim za „próbę pomieszczenia w obrębie wiary katolickiej bezwzględnego i rozpaczliwego pesymizmu" ${ }^{64}$, uznającego realność oraz ogrom zła i cierpienia, i zarazem przekraczającego go heroizmem wiary. Przekroczenie to nie umniejsza bólu, lecz zasadniczo go przemienia, ustrzegając tym samym przed popadnięciem w łatwe i powszechne uskarżanie się na los. Oprócz realizmu doświadczenia Miłosz ceni filozofię Zdziechowskiego także za możliwość pogłębienia za jej udziałem wiary, życia i myślenia religijnego. Dostrzega $\mathrm{w}$ nim chrześcijanina na serio zmagającego się z prawdami wiary

62 J. Skoczyński, Pesymizm filozoficzny Mariana Zdziechowskiego, ibidem, s. 58.

${ }^{63}$ Obok Zdziechowskiego jako bliskich sobie filozofów pesymistycznych wymienia Lwa Szestowa oraz Simone Weil, na nieco innej płaszczyźnie - także Schopenhauera. Por. Cz. Miłosz, Inne abecadło, Wydawnictwo Literackie, Kraków 1998, s. 140.

${ }^{64}$ Cz. Miłosz, Religijność Zdziechowskiego, ibidem, s. 107. 
„przeżywanej na własny rachunek”65, podejmującego „otwartą walkę z tajemnicą"66; mającego odwage "atakować ostateczne, największe sprawy"67. W latach trzydziestych Miłosz, podczas wspominanego w wierszu, niefortunnego spotkania na schodach biblioteki ${ }^{68}$, podając rektorowi książkę Oscara Miłosza, widział w nim „wybitnego myśliciela chrześcijańskiego”. Z czasem dostrzegł w nim jednego z ostatnich myślicieli religijnych. Stawiając pytanie o to, czy cena za odwrót od modernizmu nie była aż nadto wysoka, zauważa:

To, co ku niemu popychało, ta chciwość, ten niepokój, są czegoś warte, jeżeli w ogóle religia ma być czegoś warta. Jeżeli ktoś nie zgadza się ze Zdziechowskim, że tylko głos wewnętrzny, na przekór wszystkiemu, co wiemy o świecie, uchyla bramy niebios, nie znaczy to jeszcze, że ów głos da się zastąpić sylogizmami udowadniającymi istnienie Boga. A bądź co bądź moderniści, i ich sympatycy, jak Zdziechowski, byli ostatnimi myślicielami religijnymi: nie filozofami katolickimi - bo tych przyszło po nich wielu ale właśnie myślicielami, którzy sięgali w sens religii ${ }^{69}$.

Miłosz postrzega Zdziechowskiego jako pisarza żywego nurtu metafizycznego, uznając go za wyjątek w Polsce Dwudziestolecia. "A przecież owo pragnienie metafizyczne, z taką siłą przemawiające z książek Zdziechowskiego - pisze Miłosz w swoim eseju - jest czymś rzeczywistym i trwałym"70. "Zdziechowski - dodaje to nagość uczucia religijnego [...] - to również bezkompromisowość etyczna, wobec której zło jest nie do usprawiedliwienia [...] - rzecz bardzo rzadka w czasach daleko posuniętej względności"71.

Próbując dotrzeć do tego, co w autorze Pesymizmu... było zarazem wyjątkowe i ponadczasowe, Miłosz zauważa:

Kiedy powraca się do Zdziechowskiego poprzez tyle warstw naniesionych przez czas i uprzedzeń - jedno trzeba tam dostrzec: rzadko spotykane nasilenie mistycznej grozy [...] gdy odrzucić wszystkie naleciałości stylu historycznego - pozostanie człowiek zrozpaczony, samotny w obliczu Boga unoszącego się nad światem, "który nie z ręki jego wyszedł". I nie tylko człowiek jako dokument swojej epoki - ale raczej jako dokument pewnych odwiecznych spraw dzisiaj przyćmionych przez wstrzemięźliwość i zahamowania naszych środków wypowiedzi ${ }^{72}$.

Wydaje się, że zarówno te słowa, jak i inne rozpoznania pochodzące z eseju pisanego w 1943 roku, nie straciły po latach na aktualności, będąc jednym z powo-

\footnotetext{
${ }^{65}$ Ibidem, s. 117.

66 Ibidem, s. 113.

67 Ibidem, s. 111.

${ }^{68}$ Zob. m.in. Czestawa Miłosza autoportret przekorny, op. cit., s. 54 .

${ }^{69}$ Cz. Miłosz, Religijność Zdziechowskiego, op. cit., s. 114.

70 Ibidem, s. 116.

71 Ibidem.

72 Ibidem, s. 115.
} 
dów, dla których Miłosz zdecydował się przypomnieć postać Zdziechowskiego. Wybór poetyckiej tym razem formy mógł być wyrazem chęci ocalenia od zapomnienia „boskiego mędrca”. Trudno przy tym oprzeć się wrażeniu, iż szkicując portret myśliciela, autor Hymnu o Perle rozpoznaje w nim - w jakiejś mierze - własne rysy. Na pewno wspólny im obojgu był "głód Boga", duchowa tęsknota za innym wymiarem, poruszająca nie tylko intelekt, ale i wyobraźnię. Zarzut, iż „W człowieku współczesnym brak rzeczywistych przeżyć [metafizycznych - LB], poruszających wyobraźnię"73, nie dotyczył ani Zdziechowskiego, ani Miłosza. Może obaj byli w tym anachroniczni?

73 Ibidem, s. 117. 